\title{
Cloning, sequencing and expression of the gene encoding the cell-envelope-associated proteinase from Lactobacillus paracasei subsp. paracasei NCDO 151
}

\author{
ASKILd HolCK* and Helga NeS \\ MATFORSK, Norwegian Food Research Institute, Oslovn. 1, N-1430 As, Norway \\ (Received 18 November 1991; revised 10 February 1992; accepted 16 March 1992)
}

\begin{abstract}
The gene encoding the cell-envelope-associated proteinase of Lactobacillus paracasei subsp. paracasei NCDO 151 (formerly Lactobacillus casei NCDO 151) was cloned and sequenced. The gene was located on the chromosome and encoded a polypeptide of 1902 amino acids. The proteinase is $\mathbf{N}$-terminally cleaved upon maturation. It shows extensive homology to the Lactococcus lactis subsp. cremoris Wg2 proteinase. Similar to the situation in Lactococcus, a maturation gene was found upstream of the proteinase gene. The cloned proteinase gene was expressed in Lactobacillus plantarum. However, no expression was observed when the gene was cloned in Lactococcus lactis.
\end{abstract}

\section{Introduction}

The lactic acid bacteria are of great economic importance in the dairy industry. They contribute to the flavour and texture of fermented milk products (Fox, 1989; Law \& Kolstad, 1983; Thomas \& Mills, 1981). Much is known about the proteolytic systems of the lactococci. Several of the proteinases have been purified and their genes sequenced (for a review see Kok, 1990). The genes characterized so far appear to be located on plasmids.

Strains of Lactobacillus casei very often occur in hard and semihard cheeses as adventitious bacteria and in many cases contribute to flavour development during the ripening process. Consequently the proteolytic activity of $L b$. case $i$ is of interest to the dairy industry. $L b$. case $i$ has been tested for use in mixed starter cultures and shown to contribute to the production of superior-quality cheese (Girgis et al., 1983; Bianchi-Salvadori \& Sacco, 1981; Ramos et al., 1981). There has also been interest in employing heat-shocked cells or cell lysates of $L b$. casei to accelerate cheese ripening (El Abboudi et al., 1991; Trepanier et al., 1991).

Knowledge of the proteolytic systems of the lacto-

* Author for correspondence. Tel. 47-9-97 0100 ; fax 47-9-97 0333 ; email askild.holck@matforsk.nlh.no.

The nucleotide sequence data reported in this paper have been submitted to GenBank and have been assigned the accession number M83946. bacilli is limited. Some reports on characterization and partial purification of Lactobacillus proteinases have been published (Argyle et al., 1976; Ezzat et al., 1985, 1988; Khalid \& Marth, 1990; El Soda et al., 1986; Zevaco \& Gripon, 1988). We have purified to homogeneity and characterized a cell-envelope-associated proteinase of Lactobacillus paracasei subsp. paracasei NCDO 151 (formerly named Lactobacillus casei NCDO 151) (Næs et al., 1991; Næs \& Nissen-Meyer, 1992). This serine proteinase, designated Lp151, shared some properties with known lactococcal proteinases. Very little is known about the Lactobacillus proteinase genes. By Southern blotting a gene with homology to the Lactococcus lactis subsp. cremoris SK 11 proteinase gene has been observed in Lactobacillus lactis (Kok \& Venema, 1988). Kojic et al. (1991) recently reported the physical map of a proteinase gene from $L b$. casei $\mathrm{HN} 14$ with similarity to the lactococcal genes.

Here we describe the cloning, sequencing and expression of the $L b$. paracasei NCDO 151 proteinase gene. Knowledge of the genetics of the proteolytic system in lactobacilli should make it possible to construct strains with genetic characteristics important to the food fermentation industry.

\section{Methods}

Bacterial strains and plasmids. Lactobacillus paracasei subsp. paracasei NCDO 151 (formerly Lactobacillus casei NCDO 151) was obtained from the INRA Centre, Jouy-en-Josas, France. $\lambda E M B L 3, \lambda g t 10, \lambda-$ 
packaging extract plasmids pGEM-7zf(+), M13mp18, pUC19 and T7 DNA polymerase DNA sequencing kit were purchased from Promega, Biotec. $\lambda$-ladder DNA size standard ( $\lambda$ concatemers) was from BioRad. RNA molecular mass markers were obtained from Boehringer Mannheim. E. coli strains JM109, LE392, TG1, C600 Hfl, DH5 $\alpha$ and Lactobacillus plantarum NC8 were from our laboratory stock. Plasmid pVS2, conferring chloramphenicol and erythromycin resistance upon transformed cells, was a gift from Soile Tynkkynen (von Wright et al., 1987). The following gifts were obtained from Dr Jan Kok, University of Groningen, The Netherlands: Lactococcus lactis subsp. cremoris Wg2; Lc. lactis MG1363 Prt' $^{-}$(Gasson, 1983); plasmid pGKV500, harbouring the Lc. lactis $\mathrm{Wg} 2$ proteinase and maturation gene (Kok et al., 1985); and plasmid pRL12, which is pUC18 containing the ISS IW insertion element downstream of the Lc. lactis subsp. cremoris $\mathrm{Wg} 2$ proteinase maturation gene (prtM) on a $B g / I I-A c c I$ fragment (Haandrikman et al., 1990). M13 phage DNA containing the BamHI-EcoRI fragment of the Lc. lactis subsp. cremoris SK11 proteinase gene was a gift from Willem de Vos, Netherlands Institute for Dairy Research, Ede, The Netherlands (Vos et al., 1989a).

Growth of bacteria. Lb. plantarum NC8 and Lb. paracasei NCDO 151 were grown in MRS broth (Difco) and MRS broth supplemented with $20 \mathrm{mM}-\mathrm{CaCl}_{2}$ and $50 \mathrm{mM} \beta$-glycerophosphate, respectively, at $30^{\circ} \mathrm{C}$. Lc. lactis $\mathrm{Wg} 2$ and Lc. lactis $\mathrm{MG} 1363$ were grown in M17 medium (Oxoid) supplemented with $0.5 \%$ glucose. In milk-clotting experiments Lc. lactis $\mathrm{Wg} 2$ and $L$ b. plantarum $\mathrm{NC} 8$ were grown at $30^{\circ} \mathrm{C}$ in 5 or $10 \mathrm{ml}$ skimmed milk supplemented with $50 \mathrm{~mm}$ - $\beta$-glycerophosphate and $0.5 \%$ glucose. Transformants were grown in medium containing $5 \mu \mathrm{g}$ chloramphenicol $\mathrm{ml}^{-1}$.

Recombinant DNA techniques. Standard procedures were employed for general cloning techniques, largely following the procedures of Maniatis et al. (1982). Plasmid DNA from Lactobacillus was isolated by the alkaline lysis method using $20 \mathrm{mg}$ lysozyme $\mathrm{ml}^{-1}$ and $250 \mathrm{U}$ mutanolysin $\mathrm{ml}^{-1}$ in the lysis buffer. Chromosomal DNA was purified according to Marmur (1961). DNA fragments used for ligation to phage vectors and plasmids were purified from agarose gels by the freeze-squeeze method. For genomic screening of the proteinase gene (prtP), 13-20 kbp chromosomal $L b$. paracasei NCDO 151 DNA fragments obtained by partial Sau3A digestion were ligated into $\lambda$ EMBL3 vector DNA. Recombinant phages $\left(5 \times 10^{5} \mu \mathrm{g}^{-1}\right)$ were plated on $E$. coli LE392. To identify clones containing the prt $M$ gene, 4$6 \mathrm{kbp}$ chromosomal $E c o \mathrm{RI}$ fragments were ligated into $\lambda \mathrm{gt} 10$. In this case recombinant phages were plated on $E$. coli $\mathrm{C} 600 \mathrm{Hfl}$. To obtain DNA suitable for sequencing, recombinant DNA from positive $\lambda$ clones was digested with appropriate restriction enzymes and the resulting fragments were subcloned into $\mathrm{M} 13 \mathrm{mpl} 18$, pUC19 or pGEM$7 \mathrm{zf}(+)$ vector DNA. To obtain clones containing both the prtP and prt $M$ genes, 6-8 kbp HindIII fragments of chromosomal $L$ b. paracase $i$ NCDO 151 DNA were ligated with plasmid pVS2 and cloned into $L b$. plantarum NC8.

In Southern blotting experiments, DNA was transferred to nylon membranes by vacuum blotting according to the manufacturer's instructions (Pharmacia) and hybridization was performed according to Southern (1975). DNA probes were labelled with $\left[\alpha^{-32}\right.$ P $]$ dCTP by the random priming reaction (Amersham).

Transformation of lactic acid bacteria. Lc. lactis MG1363 was transformed by electroporation according to Holo \& Nes (1989). Efficiently transformable $L b$. plantarum NC8 cells were obtained by growth in MRS broth containing $1 \%(\mathrm{w} / \mathrm{v})$ glycine to an $\mathrm{OD}_{600}$ of $0 \cdot 6$. The cells were first washed with one culture volume $0.01 \mathrm{M}-\mathrm{MgCl}_{2}$ and then with $30 \%(\mathrm{w} / \mathrm{v})$ polyethylene glycol (PEG) 1500 . The cell pellet was then resuspended in $30 \%$ PEG 1500 (1/100 of the initial volume). Electroporation was subsequently performed essentially as for the lactococci $(400 \Omega, 1.5 \mathrm{kV})$.
Nucleotide sequencing. Nucleotide sequence analysis was performed by the dideoxy chain-terminating method on single-stranded M13 DNA or directly on denatured plasmid DNA (Kraft et al., 1988). Both strands were sequenced by primer walking. Oligonucleotide sequencing primers were synthesized on an Applied Biosystems synthesizer, model 381A. The computer analyses were performed on an IBM personal computer employing the DNASIS sequence analysis program (Pharmacia) and on a microVAX 3400 computer employing the GCG program package (Devereux et al., 1984).

Pulsed-field gel electrophoresis. The bacterial cells were cast and lysed within blocks of agarose (inserts) according to Lillehaug et al. (1991). Lysis was performed with $4 \mathrm{mg}$ lysozyme $\mathrm{ml}^{-1}$ and $400 \mathrm{U}$ mutanolysin $\mathrm{ml}^{-1}$. Restriction enzyme digestion was executed overnight. Pulsed field gel electrophoresis was performed on a CHEF-DR II (Bio-Rad). Electrophoreses were run under two different conditions in a $1.1 \%$ (w/v) agarose gel (in $22 \mathrm{~mm}$-Tris-base, $22 \mathrm{~mm}$-boric acid, $0.5 \mathrm{~mm}$ EDTA) at $14^{\circ} \mathrm{C}$ : either $200 \mathrm{~V}, 18 \mathrm{~h}$, pulsetime increasing from $15 \mathrm{~s}$ to $70 \mathrm{~s}$, or $200 \mathrm{~V}, 24 \mathrm{~h}$, pulsetime $1 \mathrm{~s}$ to $200 \mathrm{~s}$, according to the manufacturer's instructions.

\section{Results}

Identification and chromosomal location of the proteinase gene

To establish whether there was any similarity between the $L b$. paracasei NCDO 151 proteinase gene and the known lactococcal proteinase genes, total DNA from $L b$. paracasei NCDO 151 was subjected to restriction enzyme analysis and hybridized to a probe containing the central BamHI-EcoRI fragment of the Lc. lactis subsp. cremoris SK11 proteinase gene. The probe gave one unique signal, indicating the presence of a single-copy $L b$. paracase gene with homology to the lactococcal SK 11 gene (Fig. 1). This was confirmed by the restriction pattern obtained from several Southern blots (not shown). Similar experiments were performed with a prtMspecific probe from Lc. lactis $\mathrm{Wg} 2$ (the HindIII-ClaI fragment), and a $L b$. paracasei prt $M$ gene was detected close to the proteinase gene.

$L b$. paracasei NCDO 151 harbours two plasmids. Neither of the plasmids hybridized to the lactococcal probes (not shown). To determine whether the proteinase gene was chromosomally located or resided on a large plasmid which co-purified with the chromosomal DNA rather than with the plasmid DNA fraction, the DNA was subjected to pulsed-field gel electrophoresis under various conditions (Fig. 2). The proteinase apparently resided on a $120 \mathrm{~kb}$ NotI fragment and a Sfi fragment of $100 \mathrm{~kb}$. Moreover, the proteinase gene remained with the chromosomal DNA fraction when the cells were lysed and their DNA not digested by restriction enzymes (Fig. 2, lane 1). These experiments strongly indicated that the proteinase gene was chromosomally located.

Lc. lactis $\mathrm{Wg} 2$ and SK11 each contain the insertion sequence ISS 1 downstream of both prtM and prtP 


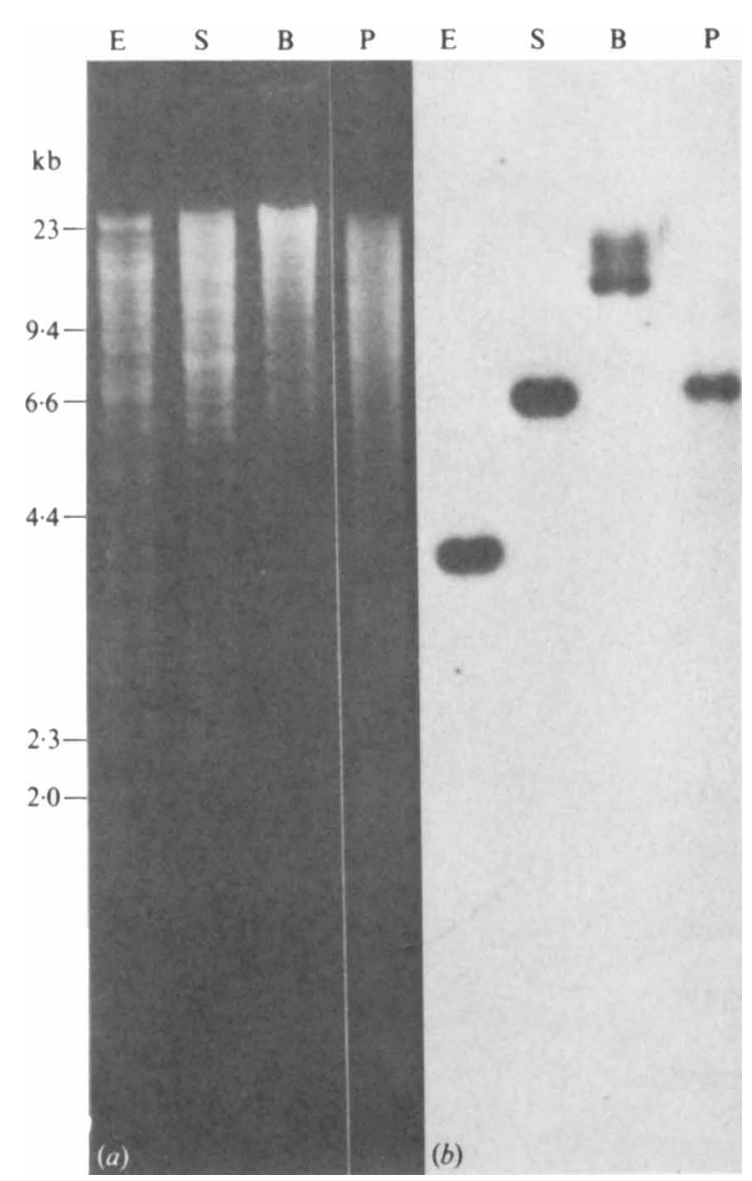

Fig. 1. Southern blot analysis of total $L b$. paracasei NCDO 151 DNA using the central $B a m H I-E c o R I$ fragment of the SK 11 proteinase gene as a probe. ( $a$ ) Ethidium-bromide-stained gel; $(b)$ autoradiography after blotting and hybridization. $\lambda$-HindIII was used as a size standard, $\mathrm{E}$, EcoRI; B, BamHI; S, SalI; P, PstI.

(Haandrikman et al., 1990). When Lb. paracasei DNA was hybridized to the $A c c I-B g l I I$ fragment of pRL12 containing the ISSIW IS element, no hybridization signals were observed, at either high or low stringency of hybridization (not shown).

\section{Cloning and sequencing of the prtP and prtM genes}

A $L b$. paracasei NCDO 151 AEMBL3 library was constructed as described in Methods and $3 \times 10^{4}$ plaques were screened with the central.BamHI-EcoRI fragment of the Lc. lactis SK11 proteinase gene as a probe. DNA from four positive clones was isolated and characterized. Various fragments containing the $5^{\prime}$, central and the $3^{\prime}$ regions of the proteinase gene were subcloned into M13 phage vector, or into pUC19 or pGEM-7zf $(+)$ plasmid vectors. None of the clones, however, contained the maturation gene prtM. A $L b$. paracasei $\lambda$ gt10 DNA library was screened with a ClaI-HindIII fragment containing the prtM gene of Lc. lactis $\mathrm{Wg} 2$. A $4.0 \mathrm{kbp}$ $E c o$ RI fragment from one of the positive clones was subcloned into pGEM-7zf(+). Appropriate subclones containing the prtP and the prt $M$ genes were sequenced. The sequence obtained was very similar to the sequence of the Lc. lactis $\mathrm{Wg} 2$ proteolytic system, but apparently carried a deletion in the promoter region common to prtM and prtP. A $6.7 \mathrm{kbp}$ chromosomal HindIII fragment of $L b$. paracasei NCDO 151 containing both the prt $P$ and prtM genes in pVS2 was obtained after screening a partial chromosomal library of HindIII fragments cloned in $L b$. plantarum NC8. This construction was named $\mathrm{pHN} 1$. Upon sequencing of the HindIII fragment, the deletion in the $\lambda \mathrm{gt} 10$ clone was shown to comprise 14 base pairs encompassing the proposed -10 region of the prtP gene. The complete sequence of both the prtP and the prtM genes is presented in Fig. 3. Two divergent open reading frames, ORF 1 and ORF2, were detected, encoding polypeptides of 299 and 1902 amino acids, respectively. The $\mathrm{N}$-terminal sequence of the mature proteinase has been determined by Edman degradation to be X-A-K-A-N-S-M-A-N (Næs \& Nissen-Meyer, 1992); this indicates the cleavage of the precursor proteinase at position +187 in the nascent polypeptide chain encoded by ORF2. This cleavage would yield an active proteinase, unless otherwise modified, of 1715 amino acid residues and an $M_{\mathrm{r}}$ of 180659. The smaller ORF1 encodes the proposed maturation protein. A typical signal sequence of lipoproteins (von Heijne, 1989) was found at the $\mathrm{N}$-terminus of the primary translation product. A presumed cleavage between amino acid 23 and 24 would give a polypeptide of 276 amino acid residues and an $M_{\mathrm{r}}$ of 30675 .

The restriction pattern for the prtP and the prt $M$ genes obtained after sequencing indicated that the $L b$. paracasei NCDO 151 proteinase was very similar to the recently identified $L b$. case $i \mathrm{HN} 14$ proteinase (Fig. 4).

When comparing the amino acid sequences of the polypeptides, the $\mathrm{Wg} 2$ and SK11 mature proteinases were found to differ from the $L b$. paracase $i$ proteinase in $58(96.6 \%$ homology) and $77(95.5 \%$ homology) amino acids, respectively (Fig. 5). When comparing the mature prtM polypeptides, the homology to the lactococcal maturation peptides was found to be $96.0 \%$.

The DNA sequence homology between the $L b$. paracasei and the lactococcal proteinase genes ended abruptly just downstream of both the prtP and prtM genes. Thus the palindromic sequences downstream of the translation stop signal, which may be involved in transcription termination, showed no similarities with the corresponding sequences of the lactococcal counterparts.

Putative Shine--Dalgarno ribosome-binding sites and -10 and -35 proposed promoter sites were located 


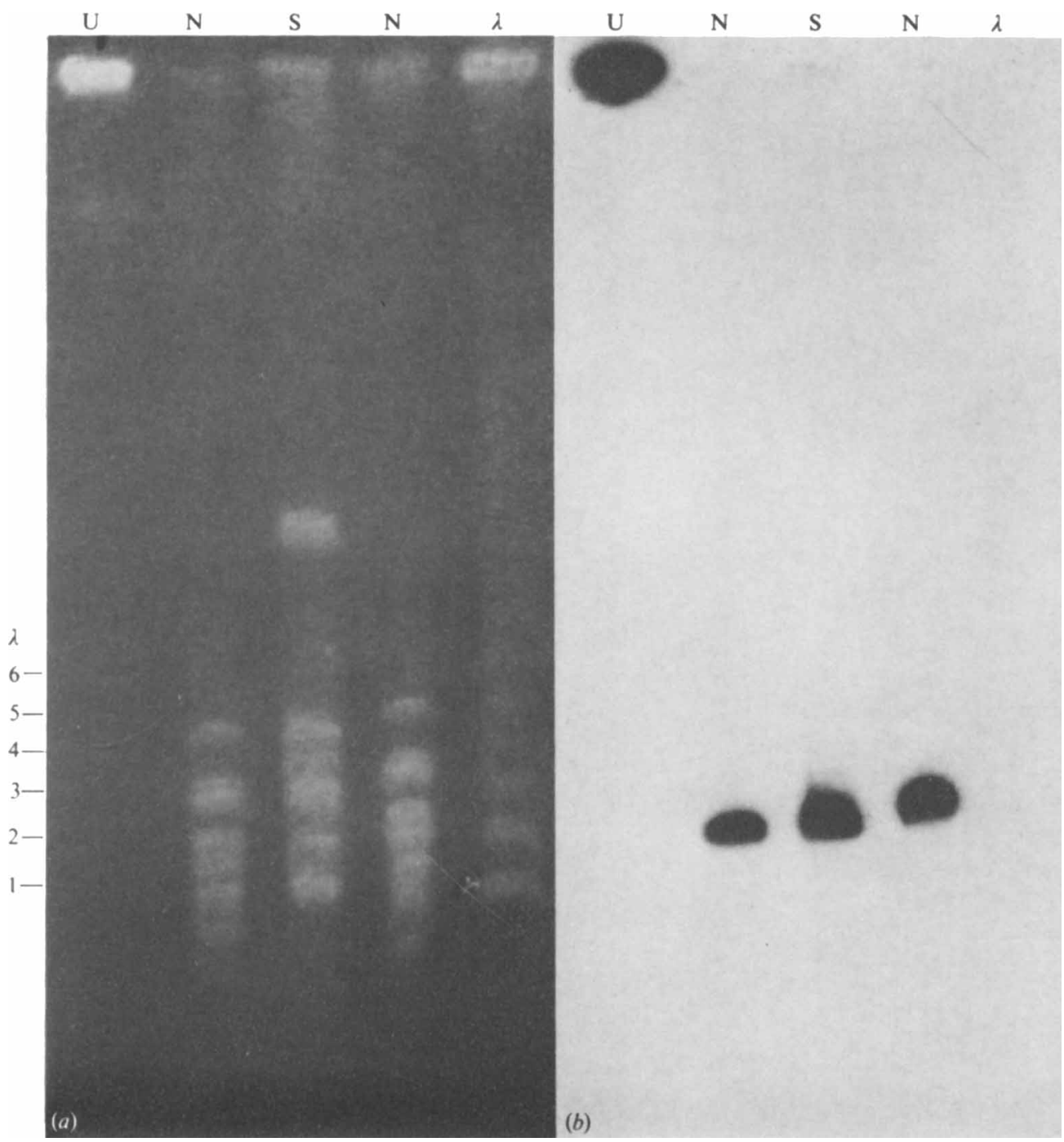

Fig. 2. Southern blot analysis of total $L b$. paracasei NCDO 151 DNA employing pulsed-field gel electrophoresis. (a) Ethidium-bromidestained agarose gel, $200 \mathrm{~V}, 18 \mathrm{~h}$, pulsetime $15-70 \mathrm{~s} ;(b)$ autoradiography after blotting and hybridization with the prtP-specific probe. U, undigested DNA; N, NotI-digested DNA; S, SfiI-digested DNA. $\lambda$, lambda ladder; one $\lambda$ unit represents $48.5 \mathrm{kbp}$.

upstream of both the prtP and prtM genes. This region also contained several palindromic sequences, two of which encompassed the two suggested -35 regions. These sequences, being able to form hairpin loops, may be involved in transcription regulation of the genes of the proteolytic system.

\section{Expression of the cloned proteinase}

No cross-hybridization was observed when $L b$. plantarum NC8 DNA was hybridized to a prtP specific probe. The weakly proteolytic $L b$. plantarum NC8 used for expression of the cloned proteinase thus contained a proteinase very different from that of $L b$. paracasei (not
Table 1. Clotting of milk by lactic acid bacteria

\begin{tabular}{lc}
\hline \hline \multicolumn{1}{c}{ Strain } & $\begin{array}{c}\text { Clotting } \\
\text { time }(\mathrm{d})^{*}\end{array}$ \\
\hline $\begin{array}{l}\text { Lb. plantarum NC8(pHN1) } \\
\text { transformant } 6\end{array}$ & $4 \pm 1$ \\
Lb. plantarum NC8(pHN1) & \\
transformant 47 & $4 \pm 1$ \\
Lb. plantarum NC8(pVS2) & $12 \pm 2$ \\
Lb. plantarum NC8 & $12 \pm 2$ \\
Lc. lactis $\mathrm{MG} 1363(\mathrm{pHN} 1) \dagger$ & - \\
Lc. lactis $\mathrm{MG} 1363$ & - \\
Lc. lactis $\mathrm{Wg} 2$ & $1 \pm 0$ \\
\hline \hline
\end{tabular}

* Experiments were performed twice, with two replicates each time. The results are means \pm range. - , No clotting observed.

† Eight transformants containing the proteinase gene were tested. 


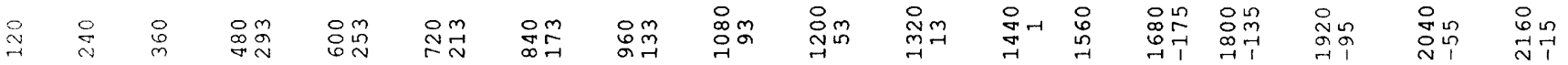

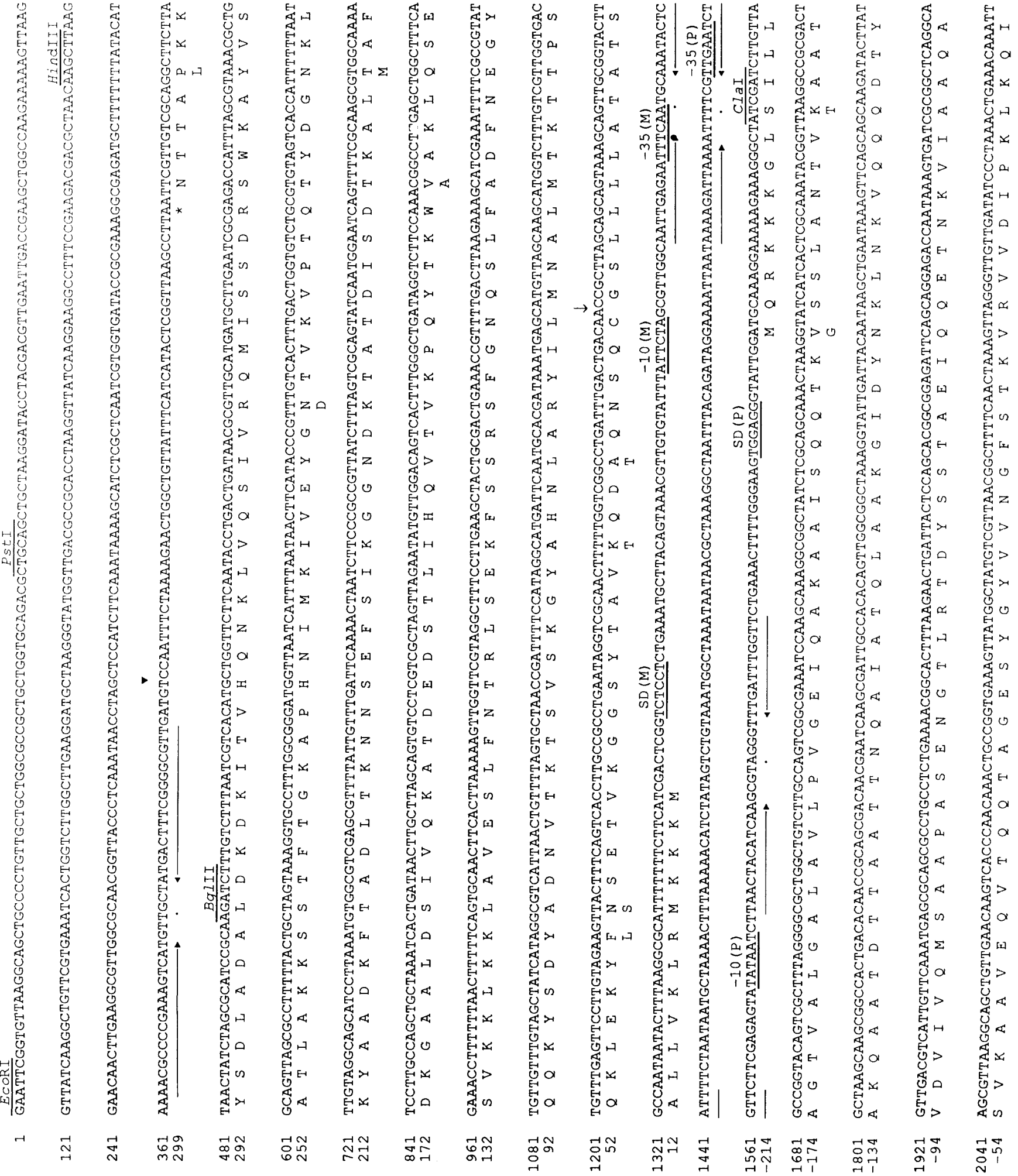




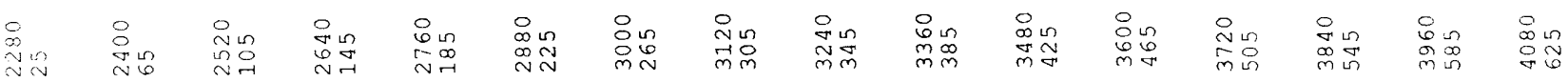

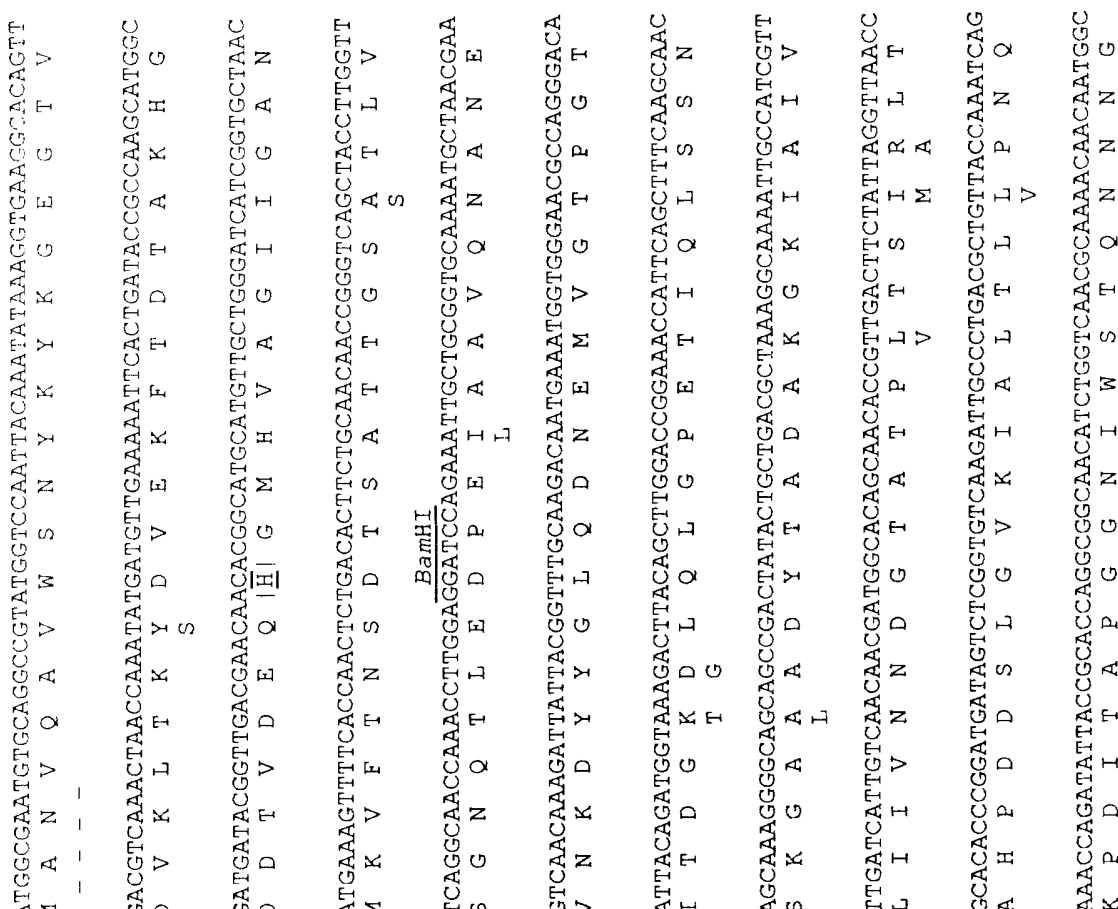

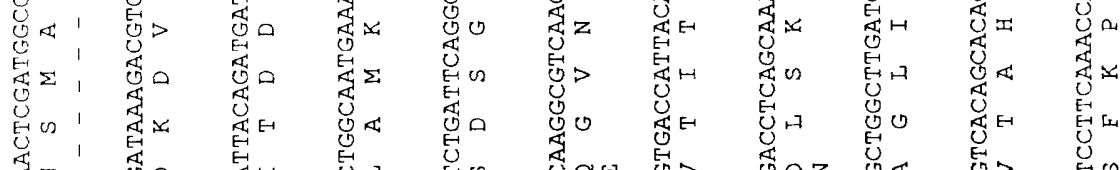

苦z:

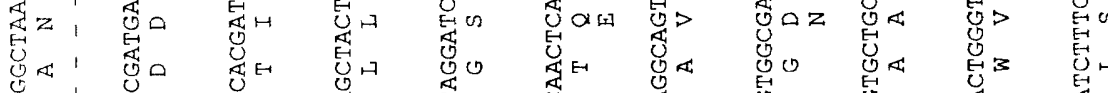

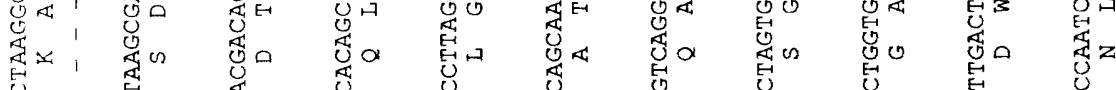

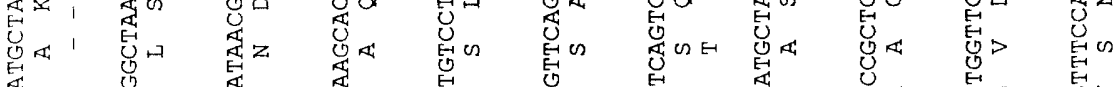

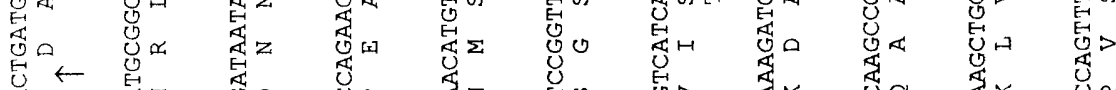

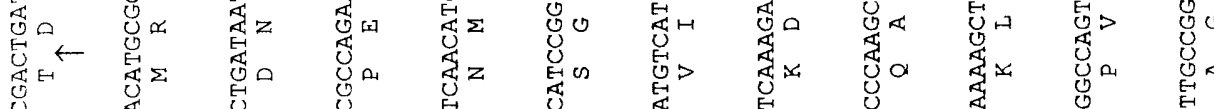

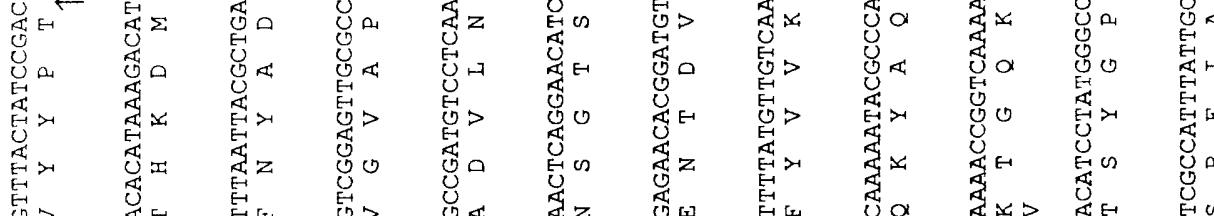

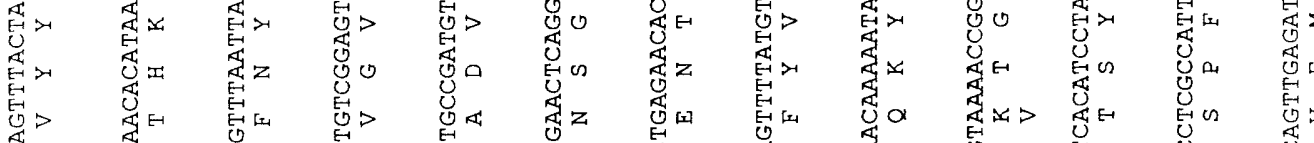

还

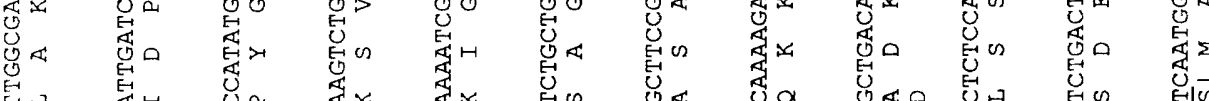

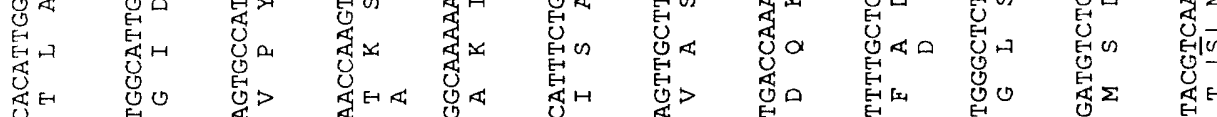

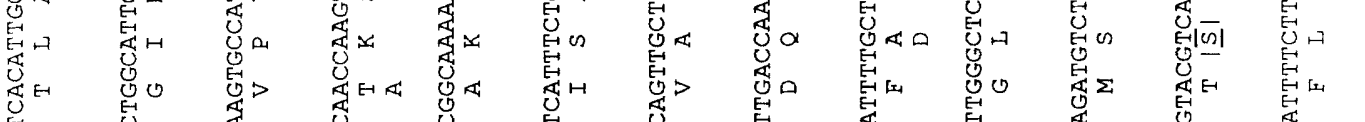

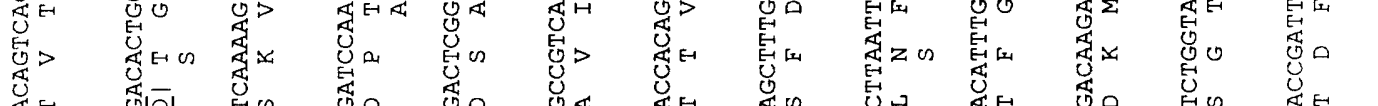

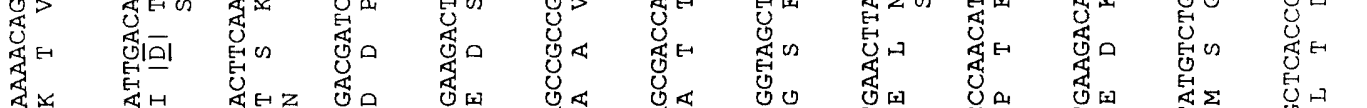

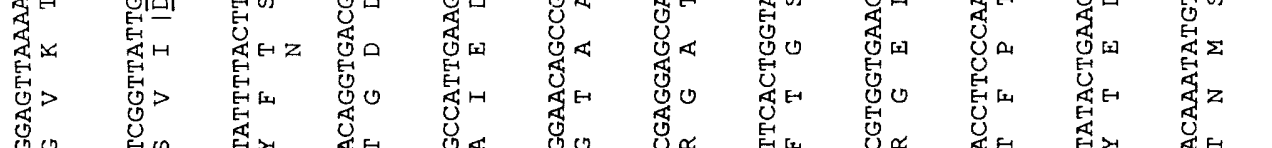

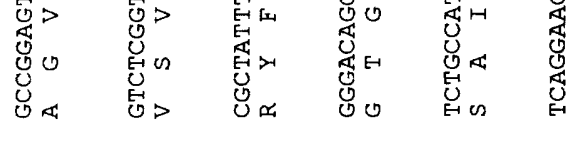

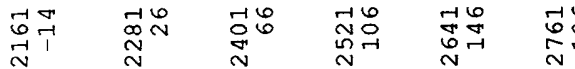

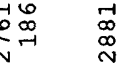

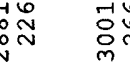




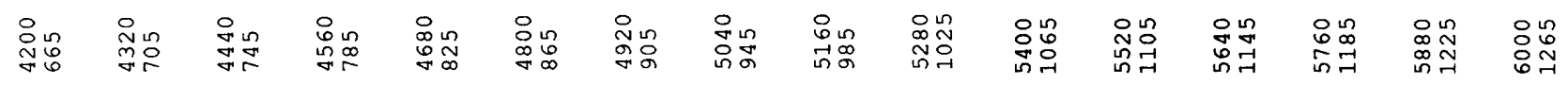

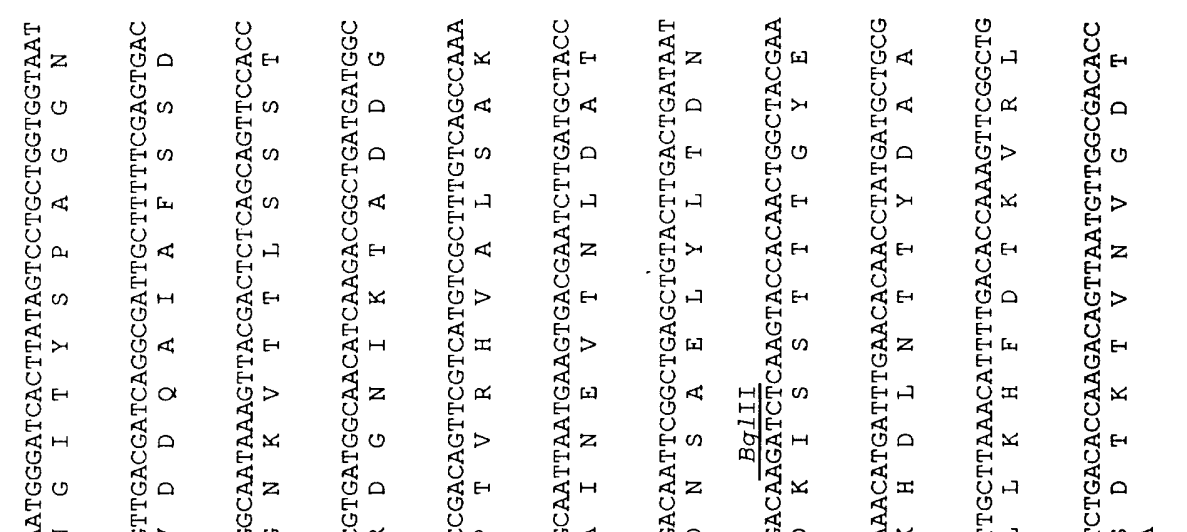

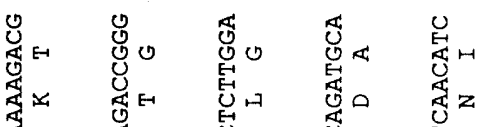

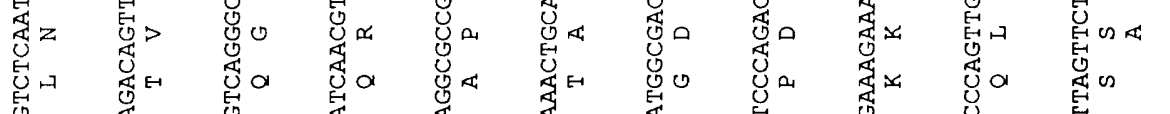

s.

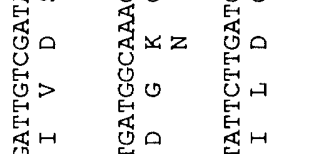

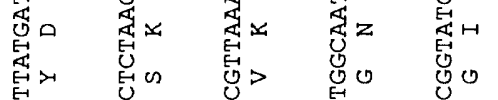

䓽

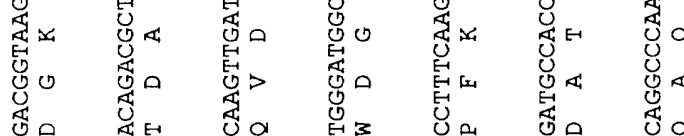

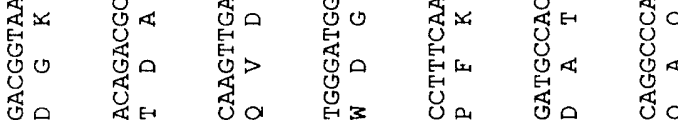

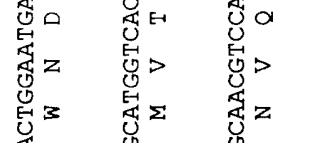

ans

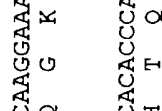

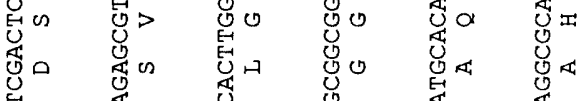

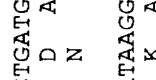

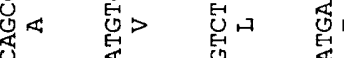

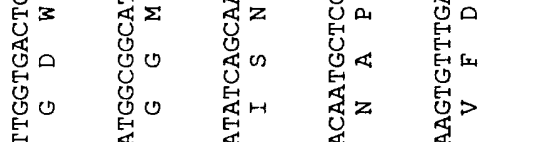

总。

悬的

(x)

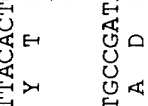

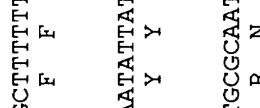

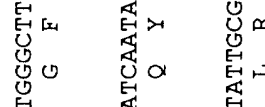

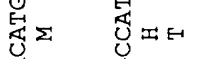

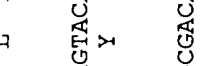

基

Uु

旨

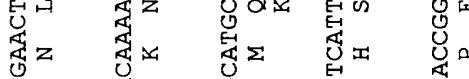

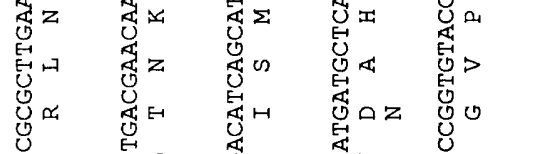

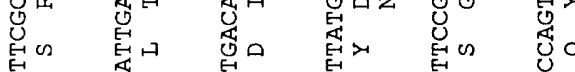

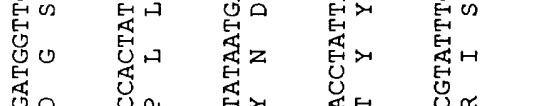

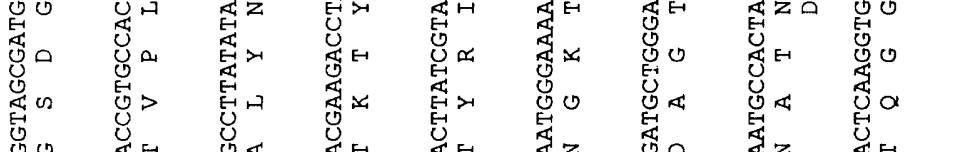

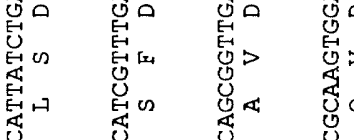

焉口

良㛣

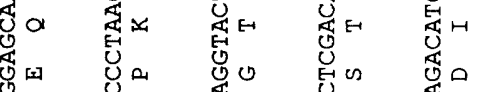

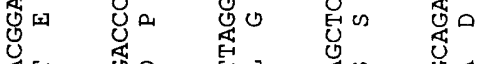

秀 $\mathrm{E}$

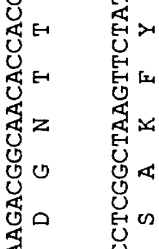

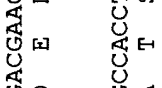

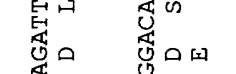

近入

发形

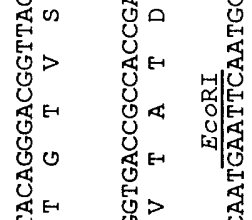

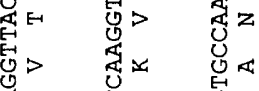

发致

震

过 $\mathrm{H}$

岁H

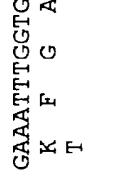

愳

Uु

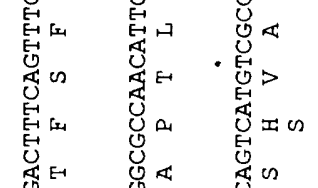

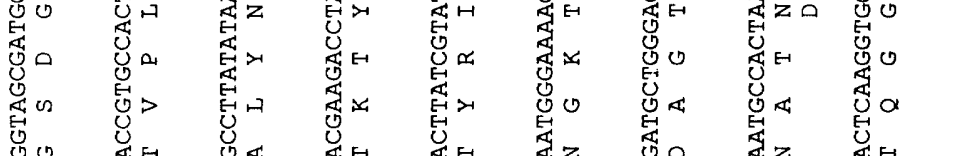

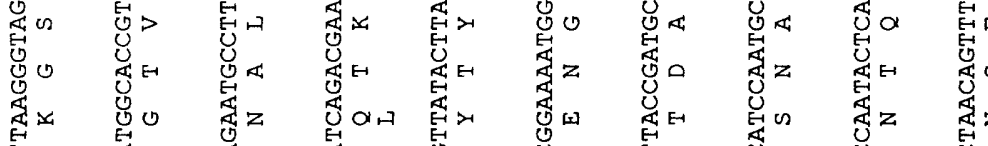

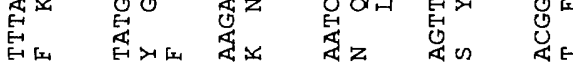

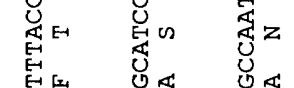

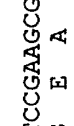

㫐佂

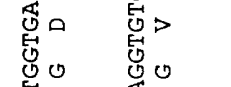

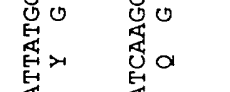

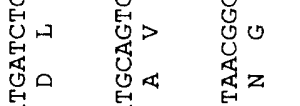

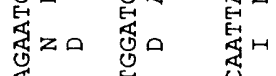

焉 总

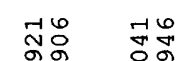

焉

諧a

至

叟>

焉

焉

岁口

近

能

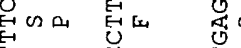

整 $\mathrm{H}$

㫐H 


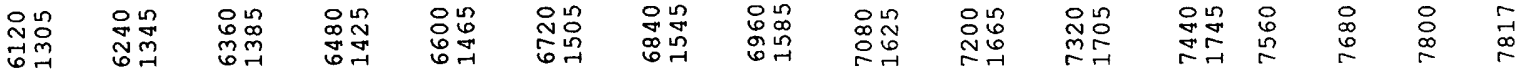

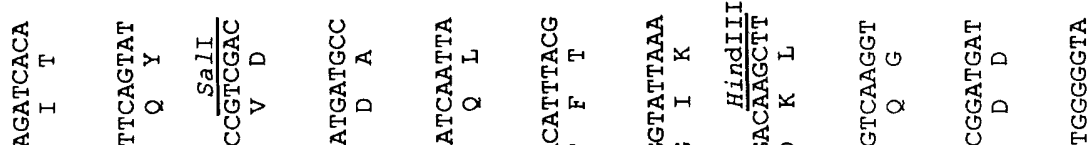

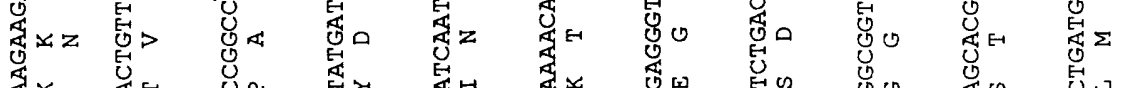

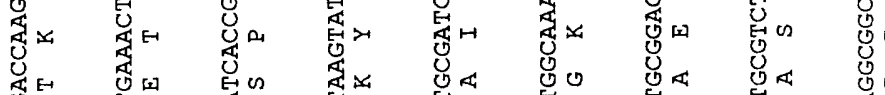

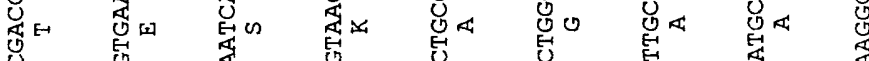

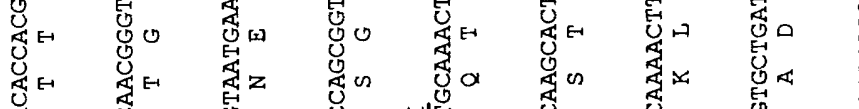

热

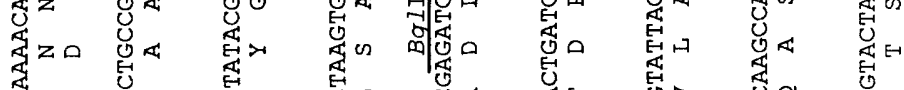

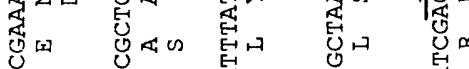

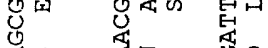

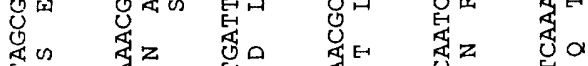

U

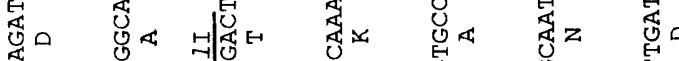

遮

曷> 嵌

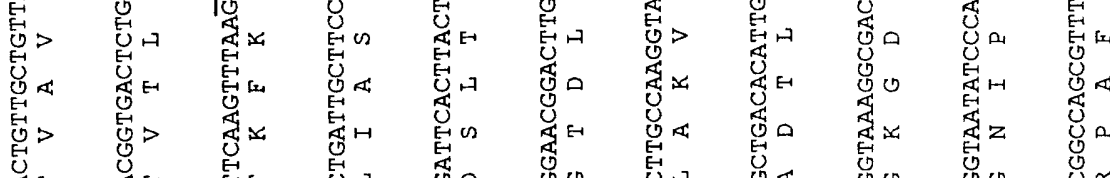

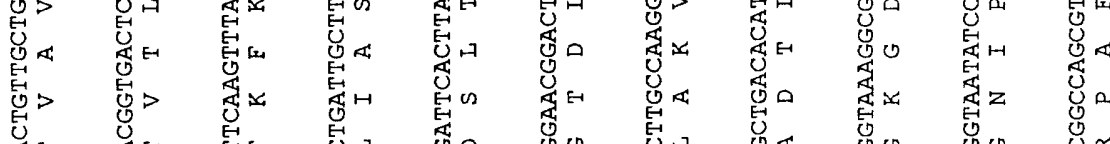

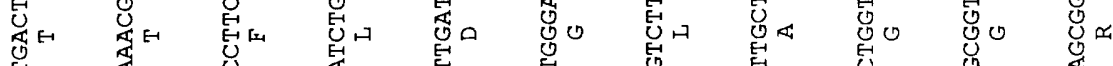

蒠

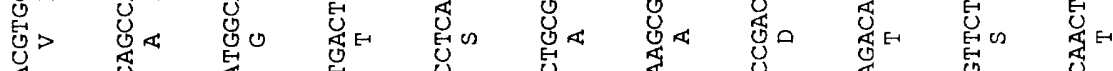

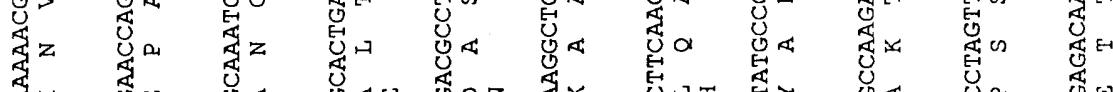

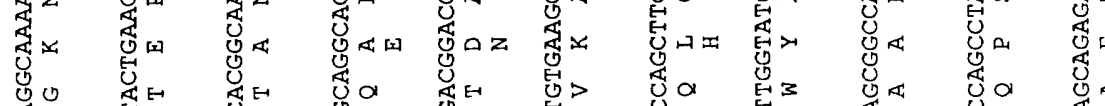

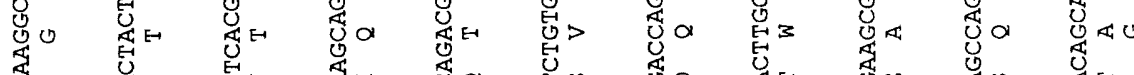

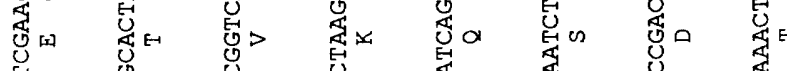

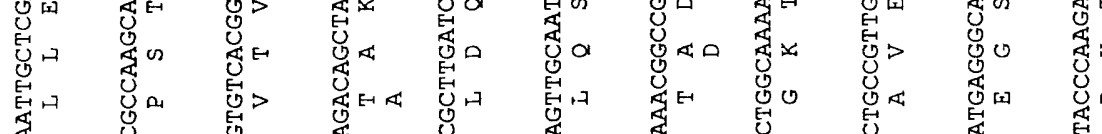

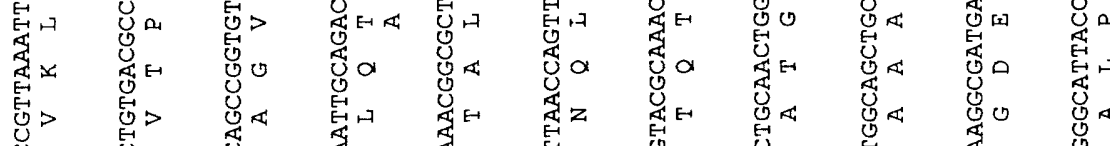

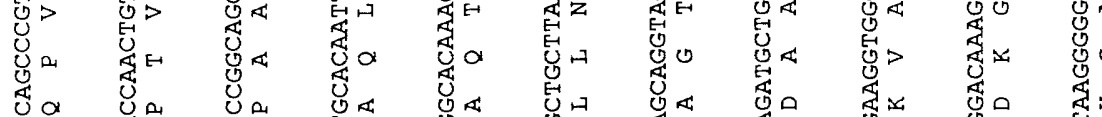

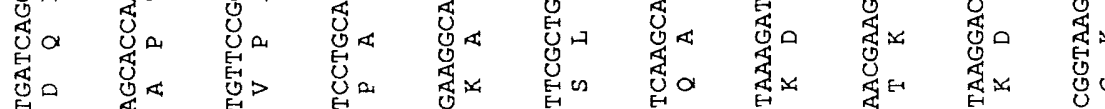

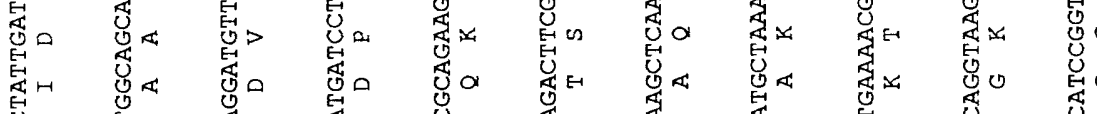

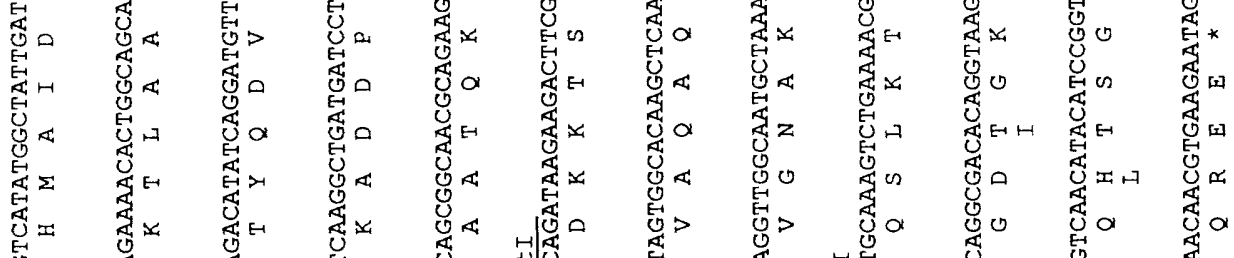

品 存

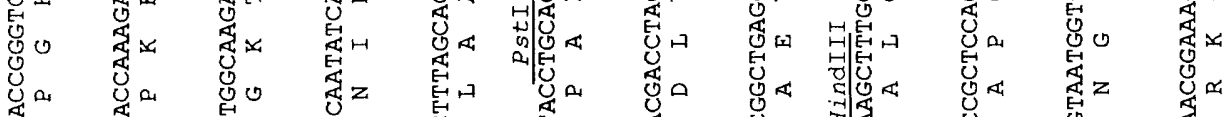

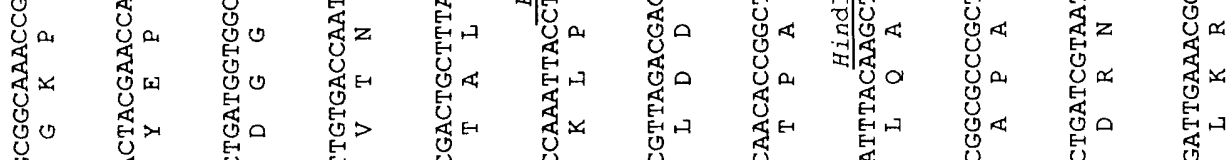

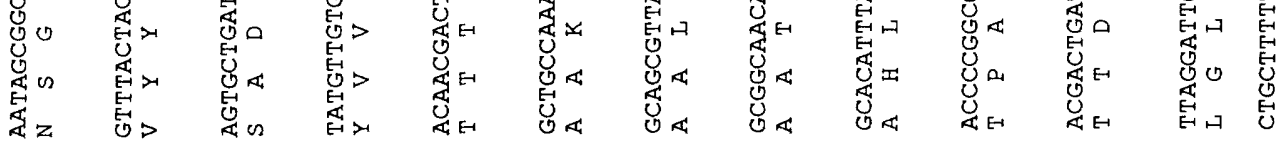

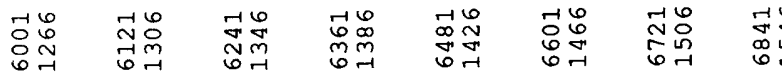

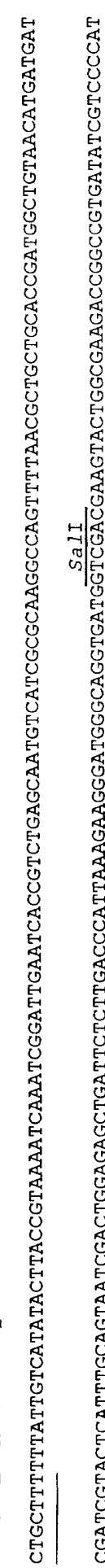

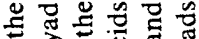

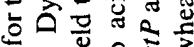

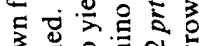

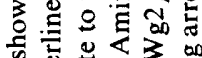

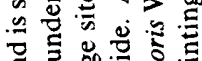

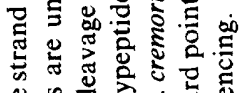

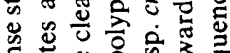

政

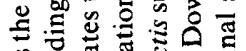

象

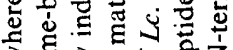

3 है उ

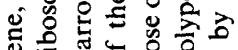

s.

讷

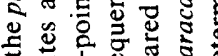

훙ㅎㅇ

:

亏

क力

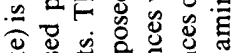

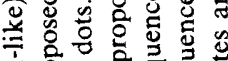

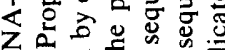

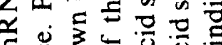

है

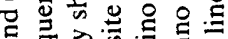

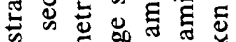

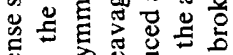

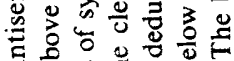

ज行

幽蛋

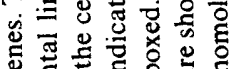

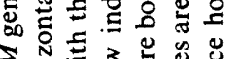

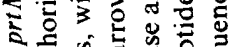

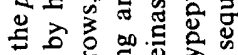

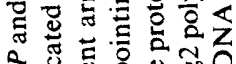

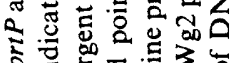

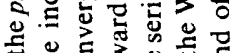

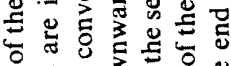

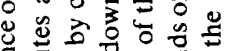

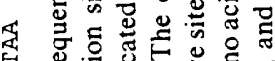

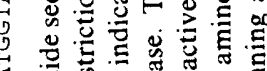

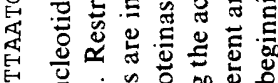

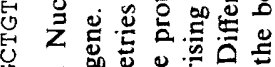

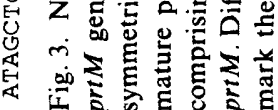


(a)

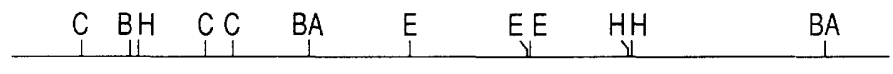

(b)

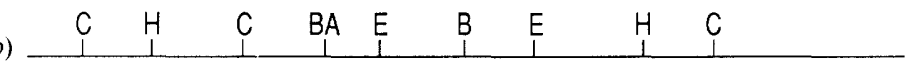

(c)

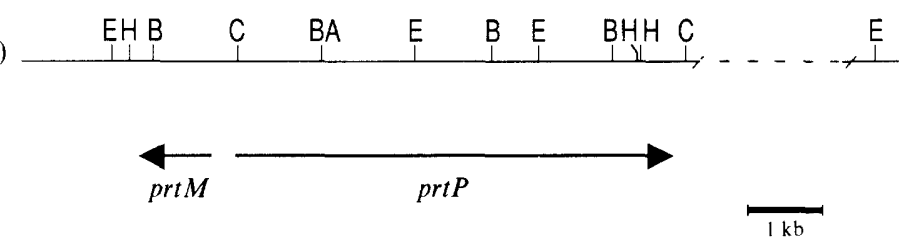

Fig. 4. Restriction enzyme maps of regions containing the proteinase and maturation genes of $(a)$ Lc. lactis subsp. cremoris $\mathrm{Wg} 2,(b)$ Lb. casei $\mathrm{HN} 14$ and (c) Lb. paracasei NCDO 151. The divergent arrows mark the positions of the prtP and prt $M$ genes. The restriction sites for $(a)$ and $(c)$ were determined by sequence analysis; those for (b) are from Kojic et al. (1991). C, ClaI; B, BglII; H, HindIII; BA, BamHI; E, EcoRI.

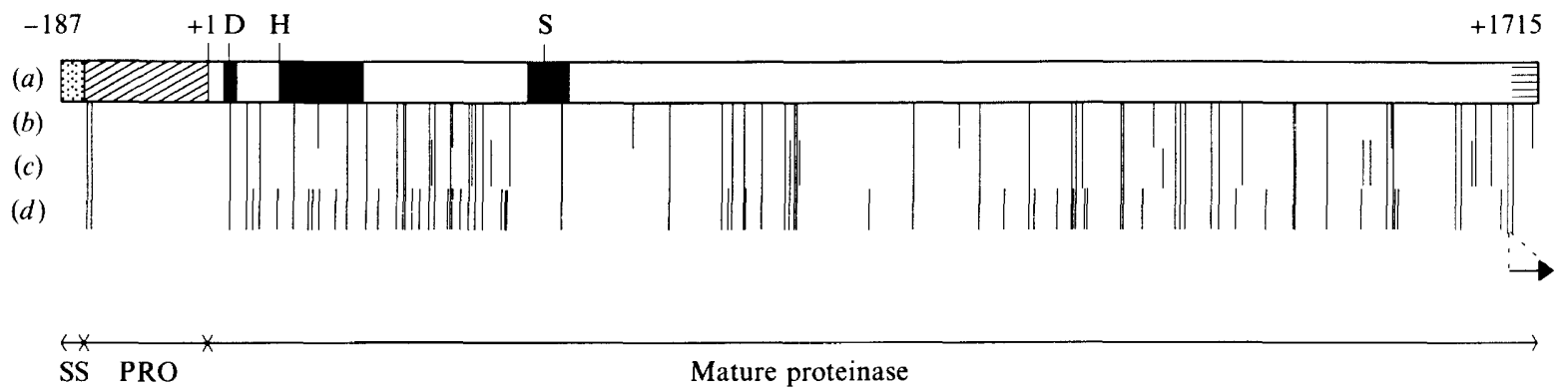

Fig. 5. Comparison of the amino acid sequences of the primary transcripts of the proteinase genes from (a) Lb.paracasei NCDO 151 , (b) Lc. lactis Wg2, (c) Lc. lactis NCDO 763 and (d) Lc. lactis SK11. Differences between the Lactobacillus and the lactococcal proteinases are shown by vertical lines. The large horizontal box indicates the Lp151 proteinase with the signal sequence (SS, stippled) and the prosequence (PRO, hatched). Black boxes mark regions with homology to subtilisins. Active-site amino acids Asp, His and Ser are indicated. Horizontal lines at the $\mathrm{C}$-terminus mark the transmembrane 'anchoring' site. The horizontal arrow indicates the C-terminal duplication of the SK 11 proteinase. The bar (top left) represents 100 amino acids.

shown). Plasmid pHN1, containing the $6.7 \mathrm{kp}$ HindIII fragment with the entire prtM gene and a slightly truncated prtP gene, was transformed into the plasmidfree $L b$. plantarum $\mathrm{NC} 8$ and the proteolytically negative Lc. lactis MG1363. Untransformed cells, and cells transformed with $\mathrm{pVS} 2$ vector or $\mathrm{pHN} 1$ were tested for activity in milk-clotting experiments (Table 1). The results showed a marked increase in proteolytic activity of $L b$. plantarum $\mathrm{NC} 8$ containing $\mathrm{pHN} 1$, whereas no expression of prtP was observed in Lc. lactis MG1363.

\section{Discussion}

When proteinase was extracted from the cell wall of $L b$. paracasei NCDO 151 and purified, two distinct fractions of proteolytic activity were obtained (Næs \& NissenMeyer, 1992). They represented two proteins, of $M_{\mathrm{r}}$ 135000 and 110000 , with an identical $\mathrm{N}$-terminal amino acid sequence. This $\mathrm{N}$-terminal sequence showed homology to the known lactococcal proteinases (Kiwaki et al., 1989; Kok et al., 1988; Nissen-Meyer \& Sletten, 1991; Vos et al., 1989a). The hybridization of total $L b$. paracasei NCDO 151 DNA clearly indicated the presence of only one chromosomal gene with homology to the lactococcal proteinases. This supports the previous conclusion that the smaller protein is a cleavage product of the larger $\left(M_{\mathrm{r}} 135000\right)$ proteinase. Catalytically active cleavage products of homologous lactococcal proteinases have been described by Nissen-Meyer \& Sletten (1991). Ezzat et al. (1988) have reported a further cell-wallbound proteolytic activity of $L b$. paracasei NCDO 151 . It is still not known whether this is another cleavage product of the Lp151 proteinase or represents a totally different proteinase.

The proteinase genes of the lactococci described so far appear to reside on plasmids. When NotI-digested total DNA from $L b$. paracasei NCDO 151 was subjected to pulsed-field gel electrophoresis, the proteinase gene appeared on a fragment of approximately $120 \mathrm{kbp}$. Such large plasmids were not observed in $L b$. paracasei NCDO 151. Plasmids are known to show varying apparent $M_{\mathrm{r}}$ 
values when subjected to pulsed-field gel electrophoresis, depending on the conditions used (S.-E. Birkeland, personal communication). For $L$ b. paracasei NCDO 151 the apparent fragment size remained unchanged, regardless of the electrophoretic conditions employed. Moreover, the $\operatorname{prt} P$-specific probe hybridized to the undigested chromosomal DNA. These experiments strongly indicated that the prtP and prt $M$ genes were chromosomally located. A recent report by Kojic et al. (1991) indicates a chromosomally located proteinase gene in $L b$. casei $\mathrm{HN} 14$. Judged by the restriction map, the proteinase genes of $L b$. case $\mathrm{HN} 14$ and $L b$. paracasei NCDO 151 appear to be very similar, but not identical.

Homologous insertion sequences or parts of insertion sequences are present downstream of both the lactococcal prt $P$ and prt $M$ genes (Haandrikman et al., 1990). The lactococcal genes thus appear to have been part of the same transposon. This is reflected in the sequence homology outside the coding regions of these genes. The prtP and prt $M$ genes of $L b$. paracase NCDO 151 do not belong to this transposon-like structure. This was verified both by the lack of hybridization to the ISS IW element of the $\mathrm{Wg} 2$ proteolytic system and by the abrupt ending of the DNA sequence homology with lactococcal prt $M$ and prtP downstream of the coding regions. It cannot be excluded, however, that the genes may be flanked by other IS elements with little homology to ISS 1 .

Sequence comparisons of homologous proteins are important in determining the amino acids responsible for the biochemical and biophysical properties of the proteins. Very few amino acid changes can lead to relatively large changes in protein properties. By construction of Wg2-SK 11 hybrid proteinases it has been shown that perhaps as few as seven amino acids were responsible for the conversion of the PI proteinase to a PIII proteinase (Vos et al., 1991). For the distantly related alkaline serine proteinases, the subtilisins, it has been shown that only three amino acid changes may lead to an increase of $7{ }^{\circ} \mathrm{C}$ in the denaturation temperature (Narhi et al., 1991). The deduced amino acid sequence of the prtP gene of $L b$. paracase NCDO 151 showed a high degree of similarity to the known sequences of the lactococcal proteinases, and much of what is known about the lactococcal proteinases is obviously valid for the Lactobacillus proteinase. It is a serine proteinase (as was indicated by its inhibition by diisopropyl fluorophosphate and phenylmethylsuphonyl fluoride (Næs et al., 1991). It is first synthesized as a pre-pro-proteinase which is cleaved upon maturation, as was indicated by the $\mathrm{N}$-terminal sequence determination (Næs \& NissenMeyer, 1992) and it contains the C-terminal hydrophobic anchor sequence that was reported for the SK11 proteinase (Vos et al., 1989a). Despite these similarities there are distinct differences between the properties of the Lactobacillus proteinase and the lactococcal proteinases. For example, when comparing the Lp151 and the 763 proteinases, the Lp151 proteinase showed a lower $\mathrm{pH}$ optimum for degrading casein (pH $5.6 \mathrm{vs} \mathrm{pH} \mathrm{6 \cdot 0-6 \cdot 3)}$ and a lower sensitivity to $\mathrm{Cu}^{2+}(28 \%$ vs $100 \%$ inhibition at $\left.1 \mathrm{mM}-\mathrm{Cu}^{2+}\right)$ (Næs et al., 1991; Monnet et al., 1987). The Lactobacillus proteinase showed a higher degree of sequence similarity to the $\mathrm{Wg} 2$ and the 763 proteinases than to the SK11 proteinase (Kiwaki et al., 1989). According to the sequence data, the Lp151 proteinase appears to be more closely related to the PI proteinases (e.g. Wg2), hydrolysing primarily $\beta$-casein, than the PIII proteinases (e.g. SK 11) hydrolysing $\alpha$-, $\beta$ - and $\kappa$-caseins. The $L b$. paracase NCDO 151 proteinase differs from the $\mathrm{Wg} 2$ proteinase in two positions regarded as important for substrate specificity and binding, namely at position 142, where Ala was found as in the SK 11 proteinase, and at position 747, where Gln was found. Also the Lp15I proteinase has retained Tyr31 and Tyr112 as in the subtilisins Carlsberg and DY (see Kok, 1990). The influence of these findings on the substrate binding and specificity is at present not known. One would perhaps expect to find differences in the digestion pattern of $\beta$ caseins between the $\mathrm{Lp} 151$ and $\mathrm{Wg} 2$ proteinases on the one hand and the 763 proteinase on the other. Even though the $\mathrm{Wg} 2$ and the 763 proteinases are $99 \%$ similar, the 763 proteinase carries the Arg 747 and Lys 748 of the SK11 proteinase which are important for substrate binding and specificity (Kiwaki et al., 1989; Vos et al., 1991). The amino acid differences between the Lactobacillus and the lactococcal proteinases appear not to be randomly scattered along the polypeptide chain (Fig. 5). Seemingly, there are long sequences where little change has occurred. The few changes found in these regions are predominantly conservative amino acid changes. The importance of these regions remains obscure. The signal sequences and the prosequences also seem to be highly conserved.

The nascent polypeptide of the Lactobacillus proteinase is cleaved at position 187. This would give a polypeptide of $M_{\mathrm{r}} 180659$.

Less is known about the PrtM protein. It is a membrane-bound lipoprotein (Haandrikman et al., $1991 a$ ) with a typical leader sequence of bacterial lipoproteins (von Heijne, 1989). It is somehow involved in the maturation of the proteinase (Haandrikman et al., $1991 b$; Vos et al., 1989b). No obvious homology to other proteins was found when searching the Swiss protein database (release 19.0) with the PrtM amino acid sequence. The known lactococcal prtM genes are virtually identical, and the amino acid changes between the Lactobacillus and the lactococcal prtM proteins appear to be randomly spread along the polypeptide 
chain. Downstream of the prtP gene, outside the region of homology to the lactococcal genes, a palindromic sequence followed by a stretch of $U$ residues was found. This may act as a transcription-terminating signal (Rosenberg \& Court, 1979). This would give a prtP mRNA of about 5860 nucleotides, which corresponds well with that observed by Northern blotting (not shown). The region upstream of the prtP gene contained putative non-overlapping promoter sequences for both the prt $P$ and the prt $M$ genes typical of $E$. coli vegetative promoters (Rosenberg \& Court, 1979). For both the prtP and $p r t M$ genes the putative -35 sequences are located within palindromic sequences, which may thus be involved in regulation of transcription. The promoter region of the prtP and prt $M$ genes carried a deletion of 30 and $34 \mathrm{bp}$ relative to the $\mathrm{Wg} 2$ and the SK 11 promoter region, respectively. The lactococcal $\operatorname{prt} M$ gene possesses two proposed promoter sites. The sequence corresponding to the more upstream -10 sequence of the lactococcal prtM gene (Kok et al., 1988) is absent in the Lactobacillus promoter. The observed lack of proteolytic activity in Lc. lactis MG1363 may be due to the loss of the upstream prt $M$ promoter.

We wish to thank Birgitta Baardsen for excellent technical assistance. This work was supported by Gilde Norge Ans.

\section{References}

Argyle, P. J., Mathison, G. E. \& Chandan R. C. (1976). Production of cell bound proteinase by Lactobacillus bulgaricus and its location in the bacterial cell. Journal of Applied Bacteriology 41, 175-186.

BIANCHI-SAlVADORI, B. \& SaCCO, M. (1981). Technology and ripening of silter cheese. Industria del Latte 17, 3-29.

DevereuX, J., Haeberli, P. \& Smithies, O. (1984). A comprehensive set of sequence analysis programs for the VAX. Nucleic Acids Research 12, 387-395.

El Abboudi, M., Pandian, S., Trepanier, G., Simard, R. E. \& Lee, B. H. (1991). Heat shocked lactobacilli for acceleration of cheddar cheese ripening. Journal of Food Science 56, 948-949.

El Soda, M., Desmazeaud, M. J., Le Bars, D. \& Zevaco, C. (1986) Cell-wall associated proteinases in Lactobacillus casei and Lactobacillus plantarum. Journal of Food Protection 49, 361-365.

Ezzat, N., El Soda, M., Bouillanne, C., Zevaco, C. \& Blanchard, P. (1985). Cell wall associated proteinases in Lactobacillus helveticus, Lactobacillus bulgaricus and Lactobacillus lactis. Milchwissenschaft $\mathbf{4 0}$, 140-143.

Ezzat, N., El Soda, M. \& El Shafei, H. (1988). The cell-bound proteinase system of Lactobacillus casei - purification and characterization. International Journal of Food Microbiology 6, 327-332.

Fox, P. F. (1989). Proteolysis during cheese manufacture and ripening. Journal of Dairy Science 72, 1379-1400.

Gasson, M. J. (1983). Plasmid complements of Streptococcus lactis NCDO 712 and other lactic streptococci after protoplast induced curing. Journal of Bacteriology 154, 1-9.

Girgis, E. S., El Koussy, L. A., Amer, S. N. \& Ewais, S. M. (1983) Effect of the type of starter culture on the properties of low fat baby edam cheese during ripening. II. Ripening progress. Egyptian Journal of Food Science 11, 45-53.

HaANDRIKMAN, A. J., KoK, J. \& Venema, G. (1991 $a$ ). Lactococcal proteinase maturation protein prtM is a lipoprotein. Journal of Bacteriology 173, 4517-4525.
Haandrikman, A. J., Meesters, R., Laan, H., Konings, W. N., KoK, J. \& Venema, G. (1991b). Processing of the lactococcal extracellular serine proteinase. Applied and Environmental Microbiology 57, 1899 1904.

Haandrikman, A. J., Van leeuwen, C., Kok, J., Vos, P., De Vos, W. M. \& Venema, G. (1990). Insertion elements on lactococcal proteinase plasmids. Applied and Environmental Microbiology 56. $1890-1896$.

vON HEIJNE, G. (1989). The structure of signal peptides from bacterial lipoproteins. Protein Engineering 2, 531-534.

Holo, H. \& Nes, I. F. (1989). High-frequency transformation, by electroporation, of Lactococcus lactis subsp. cremoris grown with glycine in osmotically stabilized media. Applied and Environmental Microbiology 55, 3119-3123.

Khalid, N. M. \& MARTH, E. H. (1990). Proteolytic activity by strains of Lactobacillus plantarum and Lactobacillus casei. Journal of Dairy Science 73, 3068-3076.

Kiwaki, M., Ikemura, H., Shimizu-Kadota, M. \& Hirashima, A (1989). Molecular characterization of a cell wall-associated proteinase gene from Streptococcus lactis NCDO 763. Molecular Microbiology 3, 359-369.

Kojic, M., Fira, D., Banina, A. \& Topisirovic, L. (1991). Characterization of the cell wall-bound proteinase of Lactobacillus casei HN14. Applied and Environmental Microbiology 57, 17531757

KoK, J. (1990). Genetics of the proteolytic system of lactic acid bacteria. FEMS Microbiology Reviews 87, 15-42.

KOK, J. \& VENEMA, G. (1988). Genetics of the proteinases of lactic acid bacteria. Biochimie 70, 475-487

KoK, J., van DiJl, J. M., van der Vossen, J. M. B. M. \& Venema, G (1985). Cloning and expression of a Streptococcus cremoris proteinase in Bacillus subtilis and Streptococcus lactis. Applied and Environmental Microbiology 50, 94-101.

KoK, J., Leenhouts, K. J., HaAndrikman, A. J., Ledeboer, A. M. \& VENEMA, G. (1988). Nucleotide sequence of the cell wall proteinase gene of Streptococcus cremoris $\mathrm{Wg} 2$. Applied and Environmental Microbiology 54, 231-238.

Kraft, R., Tardiff, J., Krauter, K. S. \& Leinwand, L. A. (1988). Using mini-prep plasmid DNA for sequencing double stranded templates with Sequenase ${ }^{\mathrm{TM}}$. Biotechniques 6, 544-547.

Law, B. A. \& Kolstad, J. (1983). Proteolytic systems in lactic acid bacteria. Antonie van Leeuwenhoek 49, 225-245.

Lillehaug, D., Lindevist, B. H. \& Birkeland, N. K. (1991). Characterization of $\phi \mathrm{LC} 3$, a Lactococcus lactis subsp. cremoris temperate bacteriophage with cohesive single-stranded DNA ends. Applied and Environmental Microbiology 57, 3206-3211

Maniatis, T., Fritsch, E. F. \& Sambrook, J. (1982). Molecular Cloning, a Laboratory Manual. Cold Spring Harbor, NY: Cold Spring Harbor Laboratory.

MARMUR, J. (1961). A procedure for isolation of deoxyribonucleic acid from microorganisms. Journal of Molecular Biology 3, 208-218.

Monnet, V., Le Bars, D. \& Gripon, J.-C. (1987). Purification and characterization of a cell wall proteinase from Streptococcus lactis NCDO 763. Journal of Dairy Research 54, 247-255.

Narhi, L. O., Stabinsky, Y., Levitt, M., Miller, L., Sachdev, R., Finley, S., Park, S., Kolvenbach, C., Arakawa, T. \& Zukowski, M. (1991). Enhanced stability of subtilisin by three point mutations. Biotechnology and Applied Biochemistry 13, 12-24.

Nissen-Meyer, J. \& SletTen, K. (1991). Purification and characterization of the free form of the lactococcal extracellular proteinase and its autoproteolytic cleavage products. Journal of General Microbiology 137, 1611-161.

N ÆS, H., Chrzanowska, J. \& Blom, H. (1991). Partial purification and characterization of a cell wall bound proteinase from Lactobacillus casei. Food Chemistry 42, 65-79.

NÆS, H. \& Nissen-Meyer, J. (1992). Purification and N-terminal amino acid determination of the cell wall bound proteinase from Lactobacillus paracasei subsp. paracasei. Journal of General Microbiology 138, 313-318.

RAMOS, M., BARNETO, R. \& ORDONEZ, J. A. (1981). Evaluation of a specific starter for manchego cheese production. Milchwissenschaft $36,528-530$. 
ROSENBERG, M. \& COURT, D. (1979). Regulatory sequences involved in the promotion and termination of RNA transcription. Annual Review of Genetics 13, 319-353.

SoutherN, E. M. (1975). Detection of specific sequences among DNA fragments separated by gel electrophoresis. Journal of Molecular Biology 98, 503-517.

Thomas, T. D. \& Mills, O. E. (1981). Proteolytic enzymes of starter bacteria. Netherlands Milk and Dairy Journal 35, 255-273.

Trepanier, G., Simard, R. E. \& Lee, B. H. (1991). Effect of added lactobacilli on composition and texture of Cheddar cheese during accelerated maturation. Journal of Food Science 56, 696-700.

Vos, P., Simons, G., Siezen, R. J. \& De Vos, W. M. (1989a). Primary structure and organization of the gene for a procaryotic, cell envelope-located serine proteinase. Journal of Biological Chemistry 264, 13579-13585.

Vos, P., Van Asseldonk, M., Van Jeveren, F., Siezen, R., Simons, G.
\& De Vos, W. M. (1989b). A maturation protein is essential for production of active forms of Lactococcus lactis SKII serine proteinase located in or secreted from the cell envelope. Journal of Bacteriology 171, 2795-2802.

Vos, P., Boerringter, I. J., Buist, G., HaAndrikman, A. J., NiJhuis, M., De Reuver, M. B., Siezen, R. J., Venema, G., De Vos, W. M. \& KoK, J. (1991). Engineering of the Lactococcus lactis serine proteinase by construction of hybrid enzymes. Protein Engineering 4 , 479-484.

von Wright, A., TyNkKynen, S. \& SuOminen, M. (1987). Cloning of a Streptococcus lactis subsp. lactis chromosomal fragment associated with the ability to grow in milk. Applied and Environmental Microbiology 53, 1584-1588.

ZeVACo, C. \& Gripon, J. C. (1988). Properties and specificity of a cellwall proteinase from Lactobacillus helveticus. Le Lait 68, 393-408. 